\title{
Urban Groundwater Quality in India
}

\author{
Nohar Singh Dahariya, Shobhana Ramteke, Bharat Lal Sahu, Khageshwar Singh Patel* \\ School of Studies in Chemistry/Environmental Science, Pt. Ravishankar Shukla University, Raipur, India \\ Email: "patelkhageshwarsingh@gmail.com
}

Received 29 February 2016; accepted 21 May 2016; published 24 May 2016

Copyright (C) 2016 by authors and Scientific Research Publishing Inc.

This work is licensed under the Creative Commons Attribution International License (CC BY).

http://creativecommons.org/licenses/by/4.0/

(C) (7) 0pen Access

\begin{abstract}
The electrical conductivity, alkalinity, salinity, hardness and chemical load of the groundwater in urban area of the country are increased enormously due to excessive urban stresses by making water unsafe for drinking purposes. Therefore, the groundwater quality of Raipur city, capital of Chhattisgarh state, India has been investigated. The physico-chemical characteristic of the groundwater along with the chemical loading variations is described. Various indices were used for rating of groundwater quality for drinking and irrigation purposes. The cluster and factor analysis models were used for source apportion of the contaminants.
\end{abstract}

\section{Keywords}

\section{Groundwater, Quality, Sources, Indices}

\section{Introduction}

The urban groundwater has emerged as one of the world's most challenging issues [1]. The quality of available groundwater resources is being increasingly degraded by geogenic and anthropogenic activities [2] [3]. Asian countries face serious water problems almost everywhere mainly due to explosive population growth, heavy seasonal rains, massive flooding, decreasing of water levels, mixing of waste water, etc. [4]. In India, groundwater is used intensively for drinking, irrigation and industrial purposes. Several land and water-based human activities are causing pollution of these precious resources. India is now the biggest user of groundwater for agriculture in the World [5]. The most dramatic change in the groundwater scenario in India is that the share of tube wells in irrigated areas is rising tremendously. By now, tube wells have become the largest single source of irrigation water in India. Hence, groundwater has a high incidence of water quality problems such as increase in concentration levels of chemical species i.e. fluoride, iron, salinity, nitrate, arsenic, etc., may be due to mineralization [6]-[15]. In the present work, the urban groundwater quality of the most industrialized city of the country, Raipur is presented. The variations and sources of contaminants and quality assessment of the groundwater are

${ }^{*}$ Corresponding author. 
described.

\section{Materials and Methods}

\subsection{Study Area}

Raipur is the capital of the Chhattisgarh state of the country with vast industrial growth having population of $>2.0$ million habitants. The groundwater is widely used for domestic, agricultural and industrial purposes. Several sponge iron, steel, alloy and cement plants are running using coal as source of energy. The water quality of city is deteriorated tremendously due to over use of groundwater and input of the industrial and sewage wastes in it [16].

\subsection{Sample Collection}

The sampling locations for the groundwater are presented in Figure 1. Fifty six groundwater samples from 28 locations of the city from the residential, urban and industrial area in two seasons (i.e. post and pre monsoon) of years, 2012 were collected by using the established methodology [17]. The water was collected into cleaned and rinsed 1 lit polyethylene flask. The physical parameters i.e. $\mathrm{pH}$, electrical conductivity (EC), dissolved oxygen (DO) and reduction potential (RP) of the groundwater were measured at the spot. The samples were dispatched to the laboratory by subsequent frizzing at $-4^{\circ} \mathrm{C}$.

\subsection{Analysis}

The total dissolved solid (TDS) value of the filtered samples (through glass fiber filter) was determined by the evaporation method [18]. The total hardness (TH) and total alkalinity (TA) values of the groundwater samples were analyzed by titration methods [19]. The CHNSO-IRMS Analyzer, SV Instruments Analytica Pvt. Ltd. was used for analysis of the dissolved organic carbon (DOC) and dissolved inorganic carbon (DIC). The Dionex DX-1100 Ion chromatograph (Dionex Corporation, Sunnyvale, CA, USA) equipped with anion and cation separation columns and conductivity detector was used for analysis of the ions. The Metrohm-781 ion meter was employed for monitoring of $\mathrm{F}^{-}$content in the presence of the buffer in 1:1 volume ratio. The buffer was prepared by dissolving sodium citrate (300 g), 1, 2-cyclohexanediamine-N-tetraaceticacid (22 g) and $\mathrm{NaCl}$ (60 g) in a volume of 1 lit with the de-ionized water by subsequent adjustment of $\mathrm{pH}$ value to $5.2 \pm 0.2$.

The indices i.e. sodium hazard (SH), magnesium hazard (MH), sodium adsorption ratio (SAR), permeability index (PI), Kelly's ratio (KR) and water quality index (WQI) were evaluated by using the following equations.

$$
\begin{aligned}
& \mathrm{SH}=(\{[\mathrm{Na}]+[\mathrm{K}]\} /\{[\mathrm{Na}]+[\mathrm{K}]+[\mathrm{Mg}]+[\mathrm{Ca}]\}) \times 100 \\
& \mathrm{MH}=\left(\left[\mathrm{Mg}^{2+}\right] /\left\{\left[\mathrm{Mg}^{2+}\right]+\left[\mathrm{Ca}^{2+}\right]\right\}\right) \times 100 \\
& \mathrm{SAR}=\left[\mathrm{Na}^{+}\right] / \sqrt{\left\{1 / 2\left(\left[\mathrm{Ca}^{2+}\right]+\left[\mathrm{Mg}^{2+}\right]\right)\right\}} \\
& \mathrm{PI}=\left(\left\{[\mathrm{Na}]+\sqrt{\left.\left.\left[\mathrm{HCO}_{3}^{-}\right]\right\} /\{[\mathrm{Na}]+[\mathrm{Mg}]+[\mathrm{Ca}]\}\right) \times 100}\right.\right. \\
& \mathrm{KR}=\left[\mathrm{Na}^{+}\right] /\left\{\left[\mathrm{Mg}^{2+}\right]+\left[\mathrm{Ca}^{2+}\right]\right\}
\end{aligned}
$$

where, all ions are expressed in meq/L

Ten parameters i.e. $\mathrm{pH}, \mathrm{EC}, \mathrm{DO}, \mathrm{TH}, \mathrm{TA}, \mathrm{Mg}^{2+}, \mathrm{Ca}^{2+}, \mathrm{Cl}^{-}, \mathrm{NO}_{3}^{-}$and $\mathrm{SO}_{4}^{2-}$ were selected for evaluation of the WQI by using the standard values recommended by BIS and WHO [20] [21]. The weighed arithmetic method was used for calculation of the WQI of the groundwater with the help of following expression.

$$
\mathrm{WQI}=\sum q_{n} W_{n} / \sum W_{n}
$$

where:

$$
q_{n}=100\left(V_{n}-V_{\text {io }}\right) /\left(S_{n}-V_{\text {io }}\right)
$$




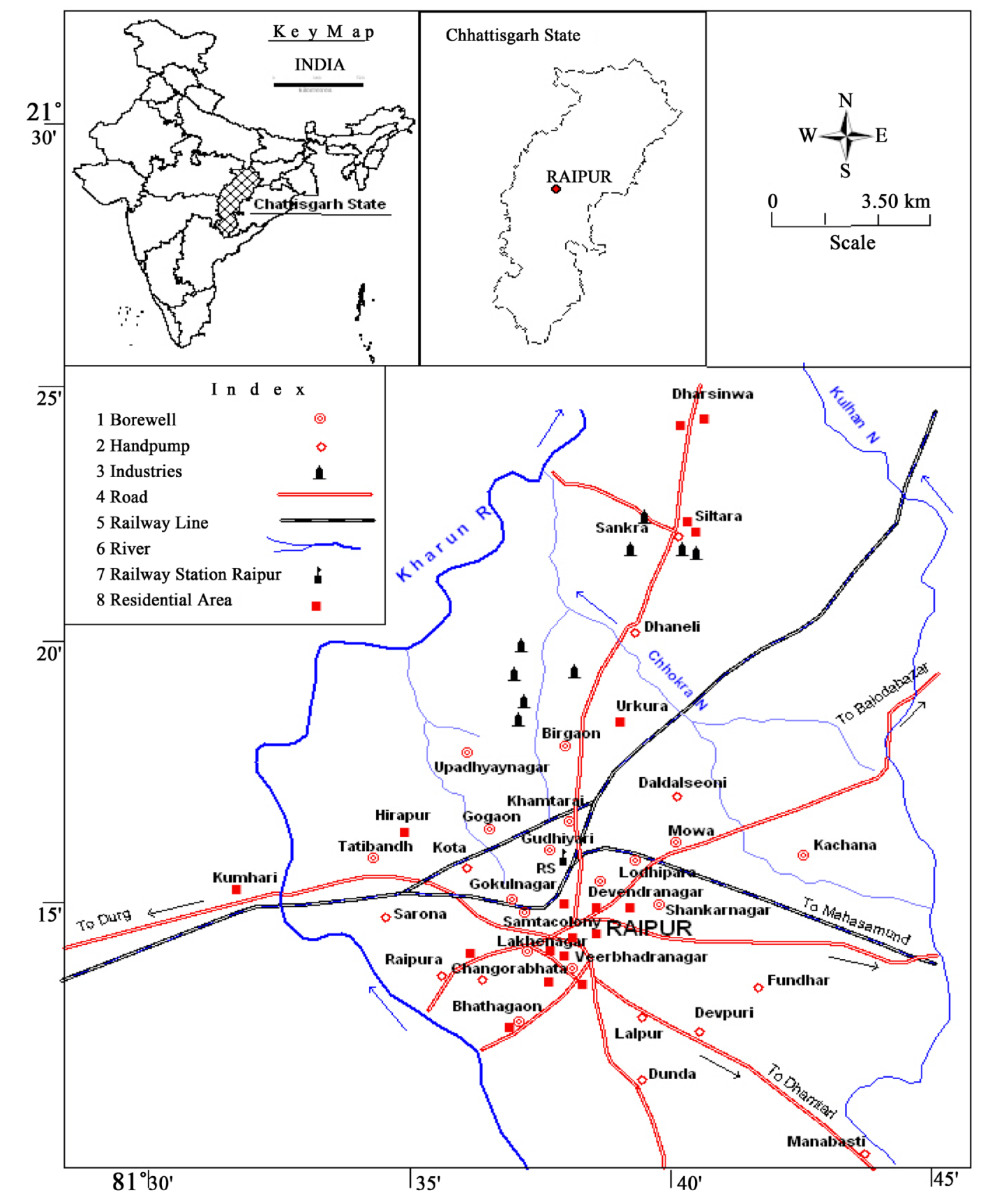

Figure 1. Representation of sampling points in Raipur city, CG, India.

$q_{n}=$ Quality rating of the nth water quality parameter

$V_{n}=$ Estimated value of the nth parameter of a given water

$S_{n}=$ Standard permissible value of the nth parameter

$V_{i o}=$ Ideal value of the nth parameter of pure water (i.e., 0 for all other parameters except $\mathrm{pH}$ and Dissolved oxygen (7.0 and $14.6 \mathrm{mg} / \mathrm{L}$, respectively)

$W_{n}=$ Unit weight for the nth parameter

$K=$ Proportionality constant 
The Aquachem water quality software was used for the preparation of Piper diagrams. Multivariate statistical analysis i.e. hierarchical cluster analysis (HCA) and factor analysis (FA) were used for apportion of contaminant sources [22]-[24]. The windows statistical software STATISTICA 7.1 was employed for the multivariate statistical calculations.

\section{Results \& Discussion}

\subsection{Geological Characteristics of Tube Wells}

The geological characteristics of the tube wells are presented in Table 1. The depth of tube wells was ranged from 30 - $150 \mathrm{~m}$ with mean value $(\mathrm{p}=0.05)$ of $90 \pm 13 \mathrm{~m}$. The age of tube wells was found in the range of 1.0 $46 \mathrm{Yr}$ with mean value $(\mathrm{p}=0.05)$ of $10 \pm 5 \mathrm{Yr}$. Generally, younger tube was found to be contaminated with higher content of ions i.e. $\mathrm{Na}^{+}, \mathrm{K}^{+}, \mathrm{Mg}^{2+}, \mathrm{Ca}^{2+}, \mathrm{Cl}^{-}, \mathrm{NO}_{3}^{-}$, and $\mathrm{SO}_{4}^{2-}$, may be due to poor scavenging fluxes. The $\mathrm{T}$ value of the groundwater was ranged from $20.1-22.9^{\circ} \mathrm{C}$ with mean value $(\mathrm{p}=0.05)$ of $21.6 \pm 0.3^{\circ} \mathrm{C}$. The slight increase with respect to increasing depth of tube well from 30 - 150 m was observed, may be due to geothermal energy.

Table 1. Geological characteristics of tube wells.

\begin{tabular}{|c|c|c|c|c|}
\hline S. No. & Location & Depth, m & Age, Yr & Environment \\
\hline 1 & Manabasti & 75 & 11 & $\mathrm{R}$ \\
\hline 2 & Dunda & 30 & 21 & $\mathrm{R}$ \\
\hline 3 & Devpuri & 90 & 6 & $\mathrm{R}$ \\
\hline 4 & Lalpur & 105 & 10 & $\mathrm{R}$ \\
\hline 5 & Fundhar & 75 & 23 & $\mathrm{R}$ \\
\hline 6 & Bhathagaon & 75 & 6 & $\mathrm{R}$ \\
\hline 7 & Changorabhatha & 75 & 11 & $\mathrm{R}$ \\
\hline 8 & Veerbhadranagar & 66 & 8 & $\mathrm{R}$ \\
\hline 9 & Raipura & 75 & 21 & $\mathrm{R}$ \\
\hline 10 & Upadhyay Nagar & 84 & 20 & $\mathrm{R}$ \\
\hline 11 & Lakhenagar & 45 & 11 & $\mathrm{R}$ \\
\hline 12 & Samta colony & 105 & 3 & $\mathrm{R}$ \\
\hline 13 & Sarona & 90 & 7 & $\mathrm{R}$ \\
\hline 14 & Gokulnagar & 60 & 2 & $\mathrm{R}$ \\
\hline 15 & Devendra & 72 & 4 & $\mathrm{R}$ \\
\hline 16 & Lodhipara & 75 & 4 & $\mathrm{R}$ \\
\hline 17 & Shankar Nagar & 75 & 6 & $\mathrm{R}$ \\
\hline 18 & Tatibandh & 90 & 16 & $\mathrm{R}$ \\
\hline 19 & Kota & 45 & 16 & $\mathrm{R}$ \\
\hline 20 & Gudhiyari & 90 & 1 & $\mathrm{C}$ \\
\hline 21 & Mowa & 150 & 2 & $\mathrm{R}$ \\
\hline 22 & Kachana & 45 & 1 & $\mathrm{R}$ \\
\hline 23 & Gogaon & 75 & 3 & $\mathrm{R}$ \\
\hline 24 & Khamtarai & 100 & 1 & C \\
\hline 25 & Daldalsiwni & 90 & 46 & $\mathrm{R}$ \\
\hline 26 & Birgaon & 135 & 1 & I \\
\hline 27 & Dhaneli & 75 & 5 & I \\
\hline 28 & Siltara & 90 & 5 & I \\
\hline
\end{tabular}

$\mathrm{C}=$ Commercial, $\mathrm{I}$ = Industrial, $\mathrm{R}=$ Residential. 


\subsection{Physico-Chemical Characteristics of Groundwater}

The physical characteristics of the groundwater of 28 locations are shown in Table 2 . The groundwater was colorless when drawn out from the tube well but after some time $(\approx 12 \mathrm{hr})$ become turbid due to precipitation of the bicarbonates as carbonates. The $\mathrm{pH}$ value of the water was ranged from $6.3-8.2$ with mean value $(\mathrm{p}=0.05)$ of $6.8 \pm 0.2$. The lowest $\mathrm{pH}$ value, 6.3 of the water was observed in the sewage dumping and industrial areas: Kachana and Siltara, due to presence of excessive levels of anions (i.e. $\mathrm{Cl}^{-}, \mathrm{NO}_{3}^{-}$and $\mathrm{SO}_{4}^{2-}$ ). In $92 \%$ locations, the $\mathrm{pH}$ values of the water were marked in the range of desirable range i.e. 6.5 - 9.2 [20]. The DO and RP values were ranged from $3.7-7.2 \mathrm{mg} / \mathrm{L}$ and $114-144 \mathrm{mV}$ with mean value $(\mathrm{p}=0.05)$ of $4.6 \pm 0.5 \mathrm{mg} / \mathrm{L}$ and $126 \pm$ $0.03 \mathrm{mV}$. The DO value of the water observed was above the recommended value of $4.0 \mathrm{mg} / \mathrm{L}$ [20] [21]. The RP value of the groundwater was found at least 5 -folds lower than the recommended value of $650 \mathrm{mV}$. Extremely high EC values of the water was marked, ranging from $1419-6300 \mu \mathrm{S} / \mathrm{cm}$ with mean value $(\mathrm{p}=0.05)$ of $2629 \pm$ $508 \mu \mathrm{S} / \mathrm{cm}$. The EC value was found to be correlated well $(\mathrm{r}=0.92)$ with the sum of total ionic concentration ions (i.e. $\mathrm{Cl}^{-}, \mathrm{NO}_{3}^{-}, \mathrm{SO}_{4}^{2-}$ and $\mathrm{Na}^{+}$). The highest $\mathrm{EC}$ value of water was marked at the location i.e. Kachana, may be due to input of the sewage waste.

Similarly, extremely high TDS, TH and TA values of the water were observed, ranging from 6338 - 14,568, $241-1432$ and $209-878 \mathrm{mg} / \mathrm{L}$ with mean value $(\mathrm{p}=0.05)$ of $10,731 \pm 603,519 \pm 130$ and $319 \pm 74 \mathrm{mg} / \mathrm{L}$,

Table 2. Mean value ( $\mathrm{n}=2$ ) of physical characteristics of groundwater in post monsoon period, January, 2012.

\begin{tabular}{|c|c|c|c|c|c|c|c|c|}
\hline S. No. & $\mathrm{pH}$ & DO mg/L & $\mathrm{T}^{\circ} \mathrm{C}$ & $\mathrm{RP}, \mathrm{mV}$ & $\mathrm{EC}, \mu \mathrm{S} / \mathrm{cm}$ & TDS, mg/L & $\mathrm{TH}, \mathrm{mg} / \mathrm{L}$ & $\mathrm{TA}, \mathrm{mg} / \mathrm{L}$ \\
\hline 1 & 6.7 & 4.7 & 21.2 & 132 & 2620 & 10,771 & 276 & 411 \\
\hline 2 & 6.5 & 6.5 & 20.1 & 116 & 3190 & 8608 & 989 & 515 \\
\hline 3 & 6.7 & 4.8 & 21.6 & 132 & 2380 & 11,111 & 431 & 362 \\
\hline 4 & 6.7 & 7.2 & 22.3 & 123 & 2600 & 6338 & 602 & 371 \\
\hline 5 & 6.9 & 4.5 & 21.4 & 132 & 3110 & 11,204 & 617 & 318 \\
\hline 6 & 7.1 & 4.3 & 21.6 & 114 & 1911 & 10,667 & 242 & 252 \\
\hline 7 & 6.7 & 4.1 & 21.6 & 126 & 2800 & 9416 & 358 & 345 \\
\hline 8 & 6.7 & 4.3 & 21.2 & 124 & 2020 & 11,593 & 405 & 209 \\
\hline 9 & 6.9 & 4.2 & 22.3 & 123 & 1945 & 9651 & 241 & 243 \\
\hline 10 & 6.9 & 4.3 & 21.2 & 134 & 1557 & 9950 & 445 & 221 \\
\hline 11 & 6.8 & 4.2 & 20.4 & 133 & 2080 & 8750 & 441 & 256 \\
\hline 12 & 7.0 & 4.5 & 22.8 & 134 & 2250 & 12,660 & 553 & 211 \\
\hline 13 & 6.8 & 3.9 & 21.6 & 123 & 2890 & 9761 & 402 & 210 \\
\hline 14 & 6.6 & 4.6 & 21.2 & 132 & 2640 & 14,002 & 529 & 262 \\
\hline 15 & 7.0 & 4.6 & 21.3 & 124 & 1419 & 10,738 & 474 & 231 \\
\hline 16 & 6.8 & 4.4 & 21.2 & 127 & 2290 & 11,035 & 341 & 251 \\
\hline 17 & 6.9 & 4.2 & 21.1 & 121 & 2020 & 10,745 & 446 & 232 \\
\hline 18 & 7.0 & 3.7 & 21.3 & 123 & 1970 & 9747 & 448 & 216 \\
\hline 19 & 6.9 & 4.9 & 22.4 & 134 & 2150 & 13,039 & 544 & 278 \\
\hline 20 & 6.8 & 5.1 & 22.2 & 140 & 2420 & 14,568 & 456 & 262 \\
\hline 21 & 6.7 & 4.7 & 22.9 & 124 & 2670 & 10,770 & 347 & 267 \\
\hline 22 & 6.3 & 6.7 & 20.4 & 128 & 6300 & 9957 & 1432 & 878 \\
\hline 23 & 6.7 & 3.8 & 21.2 & 123 & 2350 & 11,708 & 431 & 346 \\
\hline 24 & 6.9 & 4.0 & 22.6 & 134 & 2860 & 11,463 & 553 & 314 \\
\hline 25 & 6.9 & 4.9 & 21.5 & 144 & 2270 & 10,268 & 441 & 231 \\
\hline 26 & 7.1 & 4.5 & 22.7 & 130 & 3940 & 10,667 & 574 & 389 \\
\hline 27 & 8.2 & 4.2 & 21.4 & 133 & 2580 & 11,043 & 592 & 324 \\
\hline 28 & 6.3 & 3.9 & 21.9 & 131 & 4380 & 10,248 & 919 & 518 \\
\hline
\end{tabular}


respectively. The highest TDS value of the water was seen at the location: Gudhiyari may be due to huge commercial and transportation activities. However, the highest TA and TH values were recorded at location i.e. Kachana, may be due to input of the sewage waste.

The chemical characteristics of the groundwater are summarized in Table 3. The concentration of DIC and DOC was ranged from $1300-7400$ and $4500-7900 \mathrm{mg} / \mathrm{L}$ with mean value $(\mathrm{p}=0.05)$ of $4400 \pm 1300$ and 6500 $\pm 900 \mathrm{mg} / \mathrm{L}$, respectively. Similarly, the highest DIC and DOC values were marked in the water at location i.e. Gudhiyari. The DOC value of the water was several folds higher than the recommended value of $2 \mathrm{mg} / \mathrm{L}$, may be observed due to percolation of the industrial and municipal waste into the groundwater aquifer. The higher DIC value of the groundwater of this region was marked, may be due to oxidation of the DOC with the microbes.

The concentration of $\mathrm{F}^{-}, \mathrm{Cl}^{-}, \mathrm{NO}_{3}^{-}, \mathrm{SO}_{4}^{2-}, \mathrm{Na}^{+}, \mathrm{K}^{+}, \mathrm{Mg}^{2+}$ and $\mathrm{Ca}^{2+}$ in the post monsoon period was ranged from 0.4 - 1.6, 88 - 446, 46 - 991, 45 - 173, 31 - 130, 4 - 56, 16 - 84 and 56 - $256 \mathrm{mg} / \mathrm{L}$ with mean value $(\mathrm{p}=$ $0.05)$ of $1.0 \pm 0.2,224 \pm 45,206 \pm 101,105 \pm 20,60 \pm 13,18 \pm 5,28 \pm 7$ and $92 \pm 22 \mathrm{mg} / \mathrm{L}$, respectively. The highest concentration of all ions (except $\mathrm{F}^{-}$and $\mathrm{Na}^{+}$) was seen at location i.e. Kachana, may be due to input of the sewage waste. At two locations i.e. Gogaon and Khamtarai, the concentration of $\mathrm{F}^{-}$was found to be above the permissible limit of $1.5 \mathrm{mg} / \mathrm{L}$ [20] [21].

Table 3. Mean value $(\mathrm{n}=2)$ of chemical characteristics of groundwater during post monsoon period, January, 2012, $\mathrm{mg} / \mathrm{L}$.

\begin{tabular}{|c|c|c|c|c|c|c|c|c|c|c|}
\hline S. No. & DIC & DOC & $\mathrm{F}^{-}$ & $\mathrm{Cl}^{-}$ & $\mathrm{SO}_{4}^{2-}$ & $\mathrm{NO}_{3}^{-}$ & $\mathrm{Na}^{+}$ & $\mathrm{K}^{+}$ & $\mathrm{Mg}^{2+}$ & $\mathrm{Ca}^{2+}$ \\
\hline 1 & 3900 & 6600 & 1.3 & 266 & 173 & 419 & 34 & 7 & 36 & 120 \\
\hline 2 & 2500 & 5600 & 0.9 & 362 & 108 & 221 & 35 & 26 & 48 & 148 \\
\hline 3 & 5400 & 5700 & 1.4 & 220 & 110 & 351 & 49 & 10 & 34 & 108 \\
\hline 4 & 1500 & 4500 & 0.9 & 255 & 78 & 129 & 52 & 16 & 36 & 104 \\
\hline 5 & 4400 & 6800 & 1.4 & 340 & 162 & 223 & 72 & 10 & 32 & 90 \\
\hline 6 & 4300 & 6900 & 0.8 & 124 & 63 & 67 & 39 & 14 & 23 & 70 \\
\hline 7 & 3500 & 5900 & 0.9 & 276 & 118 & 74 & 87 & 26 & 31 & 104 \\
\hline 8 & 4500 & 7700 & 0.8 & 142 & 69 & 116 & 49 & 19 & 16 & 60 \\
\hline 9 & 4300 & 5700 & 1.0 & 163 & 86 & 64 & 58 & 15 & 21 & 72 \\
\hline 10 & 4500 & 5900 & 1.0 & 132 & 62 & 120 & 37 & 9 & 17 & 57 \\
\hline 11 & 3200 & 5700 & 1.5 & 134 & 68 & 193 & 62 & 13 & 23 & 72 \\
\hline 12 & 5600 & 7700 & 0.5 & 163 & 74 & 144 & 78 & 23 & 17 & 56 \\
\hline 13 & 4400 & 5600 & 1.0 & 266 & 128 & 50 & 94 & 24 & 17 & 56 \\
\hline 14 & 6700 & 7900 & 0.8 & 269 & 128 & 115 & 67 & 12 & 24 & 80 \\
\hline 15 & 4500 & 6800 & 1.1 & 88 & 45 & 131 & 31 & 14 & 22 & 68 \\
\hline 16 & 4700 & 6800 & 1.3 & 170 & 93 & 73 & 65 & 13 & 19 & 76 \\
\hline 17 & 3700 & 7600 & 0.9 & 127 & 62 & 87 & 38 & 4 & 24 & 64 \\
\hline 18 & 4600 & 5400 & 1.0 & 177 & 86 & 216 & 44 & 16 & 18 & 56 \\
\hline 19 & 5700 & 7700 & 0.9 & 177 & 88 & 377 & 50 & 11 & 26 & 80 \\
\hline 20 & 7400 & 7900 & 0.9 & 234 & 107 & 115 & 53 & 17 & 22 & 76 \\
\hline 21 & 4500 & 6600 & 0.9 & 255 & 116 & 46 & 71 & 10 & 22 & 80 \\
\hline 22 & 1300 & 6800 & 0.4 & 446 & 170 & 991 & 82 & 56 & 84 & 256 \\
\hline 23 & 4200 & 7700 & 1.6 & 251 & 114 & 216 & 37 & 16 & 30 & 100 \\
\hline 24 & 5100 & 6500 & 1.6 & 291 & 145 & 181 & 70 & 16 & 22 & 96 \\
\hline 25 & 4700 & 5900 & 0.8 & 134 & 56 & 226 & 48 & 32 & 17 & 64 \\
\hline 26 & 4600 & 5700 & 1.2 & 304 & 152 & 420 & 109 & 29 & 36 & 112 \\
\hline 27 & 4600 & 6700 & 1.3 & 191 & 110 & 58 & 130 & 29 & 29 & 98 \\
\hline 28 & 4400 & 5400 & 1.4 & 324 & 160 & 336 & 35 & 14 & 38 & 160 \\
\hline
\end{tabular}


Chloride in ground water may originate from various sources including: the dissolution of halite. The recommended tolerance limit for $\mathrm{Cl}^{-}$reported is $250 \mathrm{mg} / \mathrm{L}$ [20] [21]. The $\mathrm{Cl}^{-}$concentration beyond permissible limit was observed in the water of $50 \%$ tube wells. The ionic ratio of $\left[\mathrm{Cl}^{-}\right] /\left[\mathrm{Na}^{+}\right]$in the water was ranged from 0.9 6.8 with a mean value $(\mathrm{p}=0.05)$ of $2.7 \pm 0.5$ with exceeding of $\left[\mathrm{Cl}^{-}\right]$to $\left[\mathrm{Na}^{+}\right]$in water of the $96 \%$ tube wells, may be due to dissolution of halite minerals. The high $\mathrm{Na}^{+}$concentration (beyond $20 \mathrm{mg} / \mathrm{L}$ ) in the water may cause health hazards i.e. high blood pressure, heart disease, kidney problem, etc. In the water of all tube wells, the $\left[\mathrm{Na}^{+}\right]$was found above the limit of $20 \mathrm{mg} / \mathrm{L}$. The ionic ratio of $\left[\mathrm{Na}^{+}\right] /\left[\mathrm{K}^{+}\right]$in the water was ranged from 2 17 with a mean value $(\mathrm{p}=0.05)$ of $7 \pm 1$ similar to natural water.

High concentration of $\mathrm{SO}_{4}^{2-}(150 \mathrm{mg} / \mathrm{L})$ in groundwater of $18 \%$ tube wells was marked, ranging from 254 $2330 \mathrm{mg} / \mathrm{L}$ with mean value $(\mathrm{p}=0.05)$ of $1059 \pm 392 \mathrm{mg} / \mathrm{L}$. The water of all tube wells was contaminated with $\mathrm{NO}_{3}^{-}$above the permissible limit of $45 \mathrm{mg} / \mathrm{L}$ [20] [21]. Groundwater of $31 \%$ and $62 \%$ tube wells of the studied area was found to be contaminated with $\mathrm{Mg}^{2+}$ and $\mathrm{Ca}^{2+}$ beyond permissible limit of 30 and $75 \mathrm{mg} / \mathrm{L}$, respectively.

The domination of the DOC, DIC and $\mathrm{Cl}^{-}$in the water was observed. The chemical species i.e. carbons and ions in the water was found to occur in following decreasing order: $\mathrm{DOC}>\mathrm{DIC}>\mathrm{Cl}^{-}>\mathrm{NO}_{3}^{-}>\mathrm{SO}_{4}^{2-}>$ $\mathrm{Ca}^{2+}>\mathrm{Na}^{+}>\mathrm{Mg}^{2+}>\mathrm{K}^{+}$.

\subsection{Seasonal Variation}

The variation of ion concentration during post (January, 2012) and pre monsoon (May, 2012) periods is presented in Figure 2. The $\mathrm{T}$ value of the groundwater $(\mathrm{n}=28)$ was increased during the pre monsoon period (i.e. May, 2012) in the range of $26.0-28.0^{\circ} \mathrm{C}$ with mean value $(\mathrm{p}=0.05)$ of $27.3 \pm 0.2^{\circ} \mathrm{C}$. The value of $\mathrm{pH}, \mathrm{EC}$, TDS, $\mathrm{TH}, \mathrm{TA}, \mathrm{DOC}, \mathrm{DIC}, \mathrm{F}^{-}, \mathrm{SO}_{4}^{2-}, \mathrm{Na}^{+}, \mathrm{Mg}^{2+}$ and $\mathrm{Ca}^{2+}$ of the water was found to be increased in the pre-monsoon

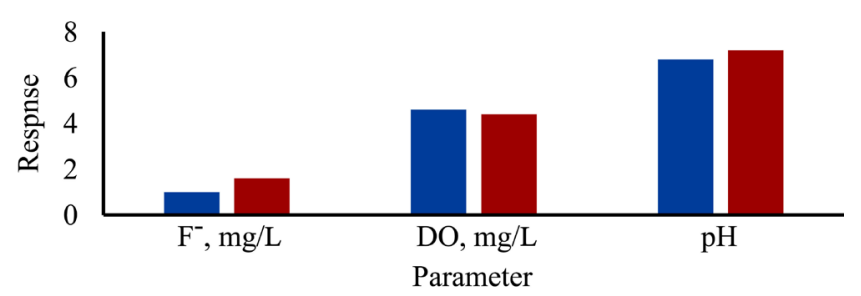

(a)

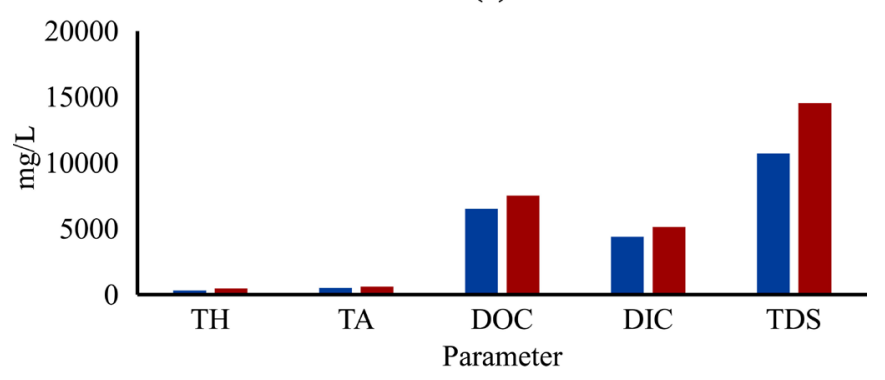

(b)

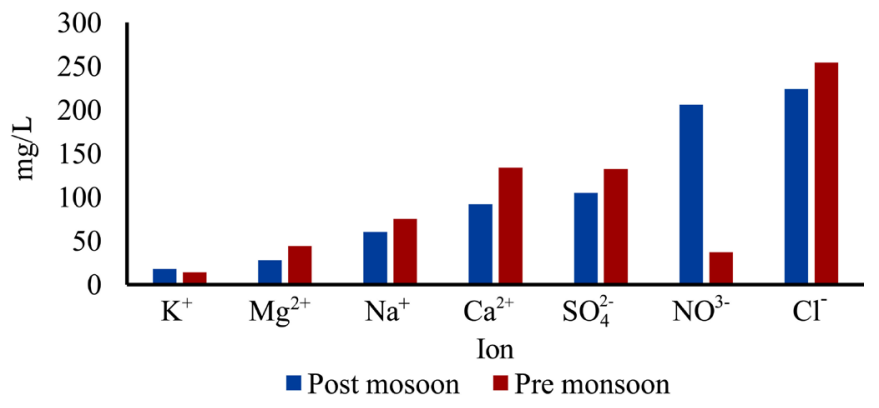

(c)

Figure 2. Parameters of groundwater during post and pre monsoon period (i.e. January, 2012 and May, 2012). 
period, may be due to increase in the water temperature, $\approx 4^{\circ} \mathrm{C}$ and shrinking of the water Table up to $\approx 30 \mathrm{~m}$. However, the concentration of ions i.e. $\mathrm{NO}_{3}^{-}$and $\mathrm{K}^{+}$was found to decrease, may be due to decrease of the anthropogenic activities.

\subsection{Sources}

In the present study, HCA was used to classify the sample sites into hydrochemical groups in the post monsoon period. The Ward's linkage method was used by using Euclidean distance for similarity measurement in the classification scheme. The result obtained by HCA detected the similar groups, yielding a dendrogram into three statistically significant clusters such as Group-I, -II and -III in the post monsoon period (Figure 3). The Group-I presented groundwater sample of location: Kachana which showed the highest values of parameters i.e. EC, TA, $\mathrm{TH}, \mathrm{NO}_{3}^{-}$and major cations (i.e. $\mathrm{K}^{+}, \mathrm{Mg}^{2+}$ and $\mathrm{Ca}^{2+}$ ) become as an outlier. The Group-II and Group-III were characterized by moderate and high pollution load of the chemicals in the groundwater, respectively.

The factor analysis (FA) derived a subset of uncorrelated variables called factors that explained the variance observed in the original dataset. In FA, all the variables were standardized at the z-scale (mean and variance set to zero and one, respectively) to minimize the effects of different units and variance of variables [25]. The FA was performed for the set of 28 sample locations with 20 variables in order to establish the association between the chemical and physical variables of the groundwater. Factor extraction was carried out by using principal components based on Kaiser Criterion [26]. Factors with eigenvalues higher than 1 were retained and presented in Table 4. Six factors explaining $84.62 \%$ of the total variance were retained after normalized varimax rotation. Factor-1 accounted for $44.18 \%$ of the total variance, revealed strong associations (high positive loadings) with TDS, EC, $\mathrm{TH}, \mathrm{Ca}^{2+}, \mathrm{Mg}^{2+}, \mathrm{Cl}^{-}, \mathrm{NO}_{3}^{-}, \mathrm{SO}_{4}^{2-}$ and TA. This factor was characterized by complex processes derived from anthropogenic sources. Factor-2 explained $11.81 \%$ of the total variance, had strong positive loadings on $\mathrm{pH}$ and $\mathrm{Na}^{+}$. Factor-2 could represent weathering of Na-bearing minerals. Factor-3 accounted for $9.69 \%$ of the total variance, had a negative loading on RP, which confirmed that RP in the groundwater did not contribute significantly to the hydrochemistry. Factor-4 accounted for $8.67 \%$ of the total variance, had a negative loading on $\mathrm{F}^{-}$. This factor did not contribute significantly to the variation of the groundwater hydrochemistry. In the same order, Factor-5 which accounted for $5.26 \%$ of the total variance, had a negative loading on depth and did not contributed significantly to the groundwater hydrochemistry. At last, factor-6 accounted for 5.01\% of the

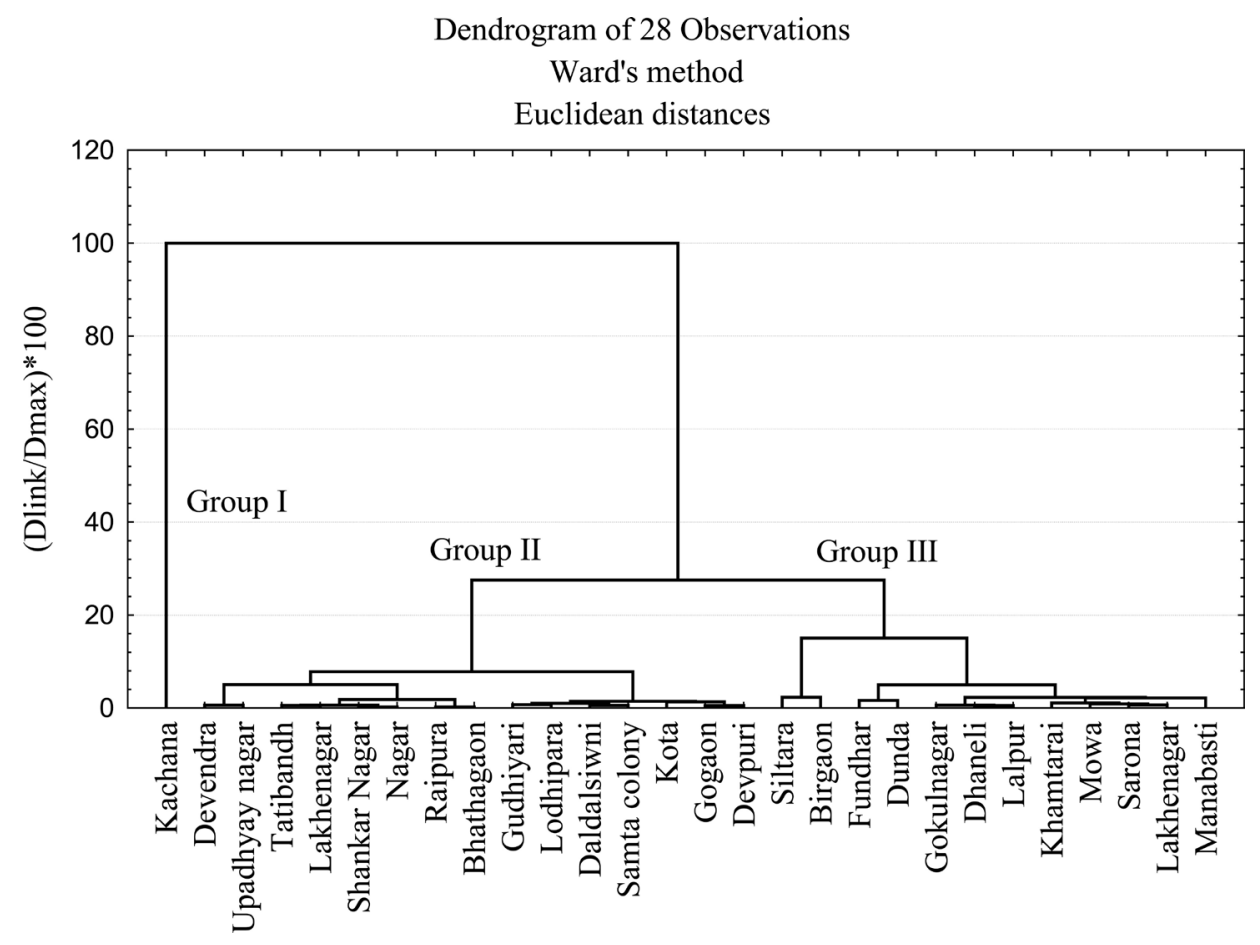

Figure 3. Dendrogram of groundwater samples in the post monsoon period, January 2012. 
Table 4. Factor analysis of variables of groundwater during post monsoon period, January, 2012.

\begin{tabular}{|c|c|c|c|c|c|c|}
\hline Parameter & Factor-1 & Factor-2 & Factor-3 & Factor-4 & Factor-5 & Factor-6 \\
\hline Depth & -0.15 & 0.12 & -0.01 & -0.02 & -0.91 & 0.03 \\
\hline Age & -0.22 & -0.00 & -0.10 & 0.06 & 0.27 & -0.74 \\
\hline $\mathrm{T}$ & -0.21 & -0.10 & -0.62 & 0.15 & 0.03 & -0.08 \\
\hline $\mathrm{pH}$ & -0.44 & 0.78 & 0.04 & -0.10 & 0.10 & 0.00 \\
\hline DO & 0.49 & -0.21 & -0.01 & 0.55 & 0.03 & -0.31 \\
\hline $\mathrm{RP}$ & 0.00 & 0.00 & -0.89 & -0.14 & 0.01 & 0.14 \\
\hline EC & 0.95 & 0.09 & 0.15 & 0.06 & -0.12 & 0.04 \\
\hline TDS & 0.96 & 0.09 & 0.15 & 0.08 & -0.10 & 0.05 \\
\hline Alk & 0.79 & 0.06 & 0.07 & 0.43 & 0.23 & 0.07 \\
\hline $\mathrm{TH}$ & 0.94 & -0.09 & 0.19 & 0.09 & 0.14 & -0.06 \\
\hline CC & -0.41 & 0.14 & -0.57 & -0.21 & -0.14 & 0.47 \\
\hline OC & -0.13 & 0.04 & -0.29 & 0.17 & 0.33 & 0.81 \\
\hline $\mathrm{F}^{-}$ & -0.02 & 0.01 & 0.00 & -0.93 & 0.00 & -0.12 \\
\hline $\mathrm{Cl}^{-}$ & 0.89 & -0.05 & 0.09 & -0.13 & -0.21 & 0.02 \\
\hline $\mathrm{SO}_{4}^{2-}$ & 0.79 & 0.07 & -0.03 & -0.44 & -0.24 & 0.17 \\
\hline $\mathrm{NO}_{3}^{-}$ & 0.85 & -0.06 & -0.09 & 0.12 & 0.23 & -0.04 \\
\hline $\mathrm{Na}^{+}$ & 0.25 & 0.86 & 0.02 & -0.01 & -0.29 & 0.09 \\
\hline $\mathrm{K}^{+}$ & 0.61 & 0.47 & 0.21 & 0.46 & 0.08 & -0.12 \\
\hline $\mathrm{Mg}^{2+}$ & 0.92 & -0.07 & 0.18 & 0.15 & 0.19 & -0.07 \\
\hline $\mathrm{Ca}^{2+}$ & 0.94 & -0.09 & 0.18 & 0.05 & 0.13 & -0.03 \\
\hline Eigen value & 8.36 & 1.72 & 1.80 & 1.97 & 1.44 & 1.63 \\
\hline Explained Variance \% & 44.18 & 11.81 & 9.69 & 8.67 & 5.26 & 5.01 \\
\hline Cumulative Variance \% & 44.18 & 55.99 & 65.68 & 74.34 & 79.61 & 84.62 \\
\hline
\end{tabular}

Significant loadings $>0.7$ (in italic and bold) at $\mathrm{p}<0.05$.

total variance, had a positive and negative loading on DOC and age which did not contribute statistically.

The results of FA in the pre monsoon period are shown in Table 5 . Three factors explaining $79.37 \%$ of the total variance were extracted. Factor- 1 accounted for $56.67 \%$ of the total variance, described complex processes such as mineralization and dissolution of evaporate in the water. Factor- 2 represented $13.44 \%$ of the total variance, had positive and negative loading on $\mathrm{NO}_{3}^{-}$and $\mathrm{pH}$, which did not contribute statistically to the hydrochemistry. Factor-2 was related to anthropogenic activities (i.e. runoff and waste water). Factor-3 was accounted for $9.26 \%$ of the total variance, had a positive and negative loading on $\mathrm{T}\left({ }^{\circ} \mathrm{C}\right)$ and $\mathrm{F}^{-}$. Factor-3 characterized the importance of temperature on the dissolution of evaporate.

\subsection{Water Quality Assessment}

As per Piper diagram, the groundwater in the post monsoon season was mostly classified into two types: Ca-Cl$\mathrm{SO}_{4}-\mathrm{NO}_{3}-\mathrm{HCO}_{3}$ and $\mathrm{Ca}-\mathrm{SO}_{4}-\mathrm{NO}_{3}-\mathrm{HCO}_{3}$ of water. The most dominating type of water was Ca-Cl- $\mathrm{SO}_{4}-\mathrm{NO}_{3}-$ $\mathrm{HCO}_{3}$. In the pre monsoon season, only Ca- $-\mathrm{SO}_{4}-\mathrm{NO}_{3}-\mathrm{HCO}_{3}$ water was observed. The WQI of the water in the post and pre monsoon period was ranged from 218 - 846 and 321 - 889 with mean value $(\mathrm{p}=0.05)$ of $361 \pm 45$ and $504 \pm 56$, respectively. The value of TDS, TH, TA, $\mathrm{F}^{-}, \mathrm{NO}_{3}^{-}, \mathrm{Cl}^{-}, \mathrm{SO}_{4}^{2-}, \mathrm{Mg}^{2+}$ and $\mathrm{Ca}^{2+}$ in the pre monsoon period was found above the recommended values of 500, 200,120, 1.5, 45, 200, 150, 30 and $75 \mathrm{mg} / \mathrm{L}$, respectively [20] [21]. These data showed that the groundwater of Raipur city was found to be unsuitable for the drinking purposes.

The values of SAR, KR, SH, MH and PI values of the groundwater in the post monsoon period were ranged from $1.3 \%-6.2 \%, 0.3 \%-2.0 \%, 26 \%-70 \%, 28 \%-38 \%$ and $47 \%-87 \%$ with mean value $(\mathrm{p}=0.05)$ of $3.0 \pm 0.5$, $0.9 \pm 0.2,48 \% \pm 4 \%, 33 \% \pm 1 \%$ and $71 \% \pm 4 \%$, respectively. Generally, the MH, SAR, KR and PI value of $<50$, 
Table 5. Factor analysis of variables of groundwater during pre monsoon period, May, 2012.

\begin{tabular}{|c|c|c|c|}
\hline Parameter & Factor-1 & Factor-2 & Factor-3 \\
\hline $\mathrm{T}\left({ }^{\circ} \mathrm{C}\right)$ & 0.05 & 0.11 & 0.75 \\
\hline $\mathrm{pH}$ & -0.26 & -0.80 & -0.14 \\
\hline EC & 0.93 & 0.07 & -0.08 \\
\hline Alk & 0.84 & 0.29 & 0.21 \\
\hline $\mathrm{TH}$ & 0.84 & 0.33 & 0.12 \\
\hline $\mathrm{F}^{-}$ & 0.09 & 0.06 & -0.81 \\
\hline $\mathrm{Cl}^{-}$ & 0.95 & 0.17 & -0.09 \\
\hline $\mathrm{SO}_{4}^{2-}$ & 0.92 & -0.22 & -0.13 \\
\hline $\mathrm{NO}_{3}^{-}$ & -0.02 & 0.81 & -0.06 \\
\hline $\mathrm{Na}^{+}$ & 0.90 & -0.03 & -0.04 \\
\hline $\mathrm{K}^{+}$ & 0.85 & 0.17 & 0.02 \\
\hline $\mathrm{Mg}^{2+}$ & 0.73 & 0.55 & 0.05 \\
\hline $\mathrm{Ca}^{2+}$ & 0.82 & 0.46 & 0.04 \\
\hline Eigenvalue & 6.85 & 2.13 & 1.34 \\
\hline Explained Variance \% & 56.67 & 13.44 & 9.26 \\
\hline Cumulative Variance \% & 56.67 & 70.11 & 79.37 \\
\hline
\end{tabular}

Significant loadings $>0.7$ (in italic and bold) at $\mathrm{p}<0.05$.

$<10,<1$ and $<25$ were considered good for the irrigation purposes [21] [27]-[29]. The SH value in the water of all tube wells was found in the range of $26 \%-70 \%$, indicating permissible water quality for the irrigation purpose [29].

\section{Conclusion}

The water of Raipur city is found to be very hard with high EC and TA values. The domination of Ca-Cl-SO ${ }_{4}^{-}$ $\mathrm{NO}_{3}-\mathrm{HCO}_{3}$ type water was observed, may be due to huge industrial and urban activities. The quality of water was found to be deteriorated due to excessive mineralization of species i.e. DOC, DIC, $\mathrm{Cl}^{-}, \mathrm{NO}_{3}^{-}, \mathrm{SO}_{4}^{2-}$, $\mathrm{HCO}_{3}^{-}, \mathrm{Na}^{+}, \mathrm{K}^{+}, \mathrm{Mg}^{2+}$ and $\mathrm{Ca}^{2+}$, and not found to be suitable for drinking purposes.

\section{Acknowledgements}

We are thankful to the UGC, New Delhi for awarding the RG scholarship to one of the author, NSD for doing this work.

\section{References}

[1] Tellam, J.H., Rivett, M.O., Israfilov, R.G. and Herringshaw, L.G. (2006) Urban Groundwater Management and Sustainability. Springer, Berlin. http://dx.doi.org/10.1007/1-4020-5175-1

[2] Jain, S.K. (2012) Sustainable Water Management in India Considering likely Climate and Other Changes. Current Sciences, 102, 177-188.

[3] Schwarzenbach, R.P., Egli, T., Hofstetter, T.B., Gunten, U.V. and Wehrli, B. (2010) Global Water Pollution and Human Health. Annual Review of Environment and Resources, 35, 109-136. http://dx.doi.org/10.1146/annurev-environ-100809-125342

[4] Biswas, A.K. and Seetharam, K.E. (2008) Achieving Water Security for Asia. Water Resources Development, 24, 145176. http://dx.doi.org/10.1080/07900620701760556

[5] Hah, T. (2009) Taming the Anarchy: Groundwater Governance in South Asia. Resources for the Future. Washington, DC, USA and International Water Management Institute, Colombo, 310. http://hdl.handle.net/10568/36566

[6] Basavarajappa, H.T. and Manjunatha, M.C. (2015) Groundwater Quality Analysis in Precambrian Rocks of Chitradurga District, Karnataka, India using Geo-Informatics Techdnique. Aquatic Procedia, 4, 1354-1365. 
http://dx.doi.org/10.1016/j.aqpro.2015.02.176

[7] Chakraborti, D., Das, B. and Murrill, M.T. (2011) Examining India’s Groundwater Quality Management. Environmental Science and Technology, 45, 27-33. http://dx.doi.org/10.1021/es101695d

[8] Dagar, J.C. (2005) Salinity Research in India: An Overview. Bulletin of the National Institute of Ecology, 15, 69-80.

[9] Dar, I.A., Sankar, K. and Dar, M.A. (2011) Spatial Assessment of Groundwater Quality in Mamundiyar Basin, Tamil Nadu, India. Environmental Monitoring and Assessment, 178, 437-447. http://dx.doi.org/10.1007/s10661-010-1702-2

[10] Ramesh, K. and Elango, L. (2012) Groundwater Quality and Its Suitability for Domestic and Agricultural use in TondiarRiver Basin, Tamil Nadu, India. Environmental Monitoring and Assessment, 184, 3887-3899. http://dx.doi.org/10.1007/s10661-011-2231-3

[11] Rosin, K.G., Kaur, R., Singh, S.D., Singh, P. and Dubey, D.S. (2013) Groundwater Vulnerability to Contaminated Irrigation Waters-A Case of Peri-Urban Agricultural Lands around an Industrial District of Haryana, India. Procedia Environmental Sciences, 18, 200-210. http://dx.doi.org/10.1016/j.proenv.2013.04.026

[12] Rao, N.S. (2008) Iron Content in Groundwater of Visakhapatnam Environs, Andhra Pradesh, India. Environmental Monitoring and Assessment, 136, 437-447.

[13] Tank, D.K. and Chandel, C.P.S. (2010) A Hydrochemical Elucidation of the Groundwater Composition under Domestic and Irrigated Land in Jaipur City. Environmental Monitoring and Assessment, 166, 69-77. http://dx.doi.org/10.1007/s10661-009-0985-7

[14] Venkateswaran, S. and Deepa, S. (2015) Assessment of Groundwater Quality Using GIS Techniques in Vaniyar Watershed, Ponnaiyar River, Tamil Nadu. Aquatic Procedia, 4, 1283-1290. http://dx.doi.org/10.1016/j.aqpro.2015.02.167

[15] Vijay, R., Khobragade, P. and Mohapatra, P.K. (2011) Assessment of Groundwater Quality in Puri City, India: An Impact of Anthropogenic Activities. Environmental Monitoring and Assessment, 177, 409-418. http://dx.doi.org/10.1007/s10661-010-1643-9

[16] Patel, K.S., Dahariya, N.S., Chakradhari, S., Sahu, P., Rajhans, K.P., Ramteke, S., Lata, L. and Milosh, H. (2015) Sewage Pollution in Central India. American Journal of Analytical Chemistry, 6, 787-796. http://dx.doi.org/10.4236/ajac.2015.610075

[17] Nielsen, D.M. and Nielsen, G.L. (2000) The Essential Handbook of Groundwater Sampling. CRC Press, Boca Raton, USA.

[18] APHA (2005) Standard Methods for the Examination of Water and Wastewater. 21st Edition, APHA, AWWA and WEF, Washington DC.

[19] Nollet Leo, M.L. and De Gelder Leen, S.P. (2007) Handbook of Water Analysis. 2nd Edition, CRC Press, Boca Raton.

[20] BIS (Bureau of Indian Standard) (2009) Drinking Water-Specification. 2nd Edition, New Delhi. http://bis.org.in/sf/fad/FAD25(2047)C.pdf

[21] WHO (2011) Guidelines for Drinking-Water Quality. 4th Edition, World Health Organization, Geneva. http://www.who.int/water_sanitation_health/publications/2011/dwq_chapters/en/

[22] Liu, C.W., Lin, K.H. and Kuo, Y.M. (2003) Application of Factor Analysis in the Assessment of Groundwater Quality in a Blackfoot Disease Area in Taiwan. Science of the Total Environment, 313, 77-89. http://dx.doi.org/10.1016/S0048-9697(02)00683-6

[23] Reghunath, R., Murthy, T.R.S. and Raghavan, B.R. (2002) The Utility of Multivariate Statistical Techniques in Hydrogeochemical Studies: An Example from Karnataka, India. Water Resources, 36, 2437-2442.

[24] Shrestha, S. and Kazama, F. (2007) Assessment of Surface Water Quality Using Multivariate Statistical Techniques: A Case Study of the Fuji River Basin, Japan. Environmental Modelling and Software, 22, 464-475. http://dx.doi.org/10.1016/j.envsoft.2006.02.001

[25] Singh, K.P., Malik, A., Mohan, D. and Sinha, S. (2004) Multivariate Statistical Techniques for the Evaluation of Spatial and Temporal Variations in Water Quality of Gomti River (India): A Case Study. Water Resources, 38, 3980-3992. http://dx.doi.org/10.1016/j.watres.2004.06.011

[26] Kaiser, H.F. (1958) The Varimax Criterion for Analytical Rotation in Factor Analysis. Psychometrika, 23,187-200. http://dx.doi.org/10.1007/BF02289233

[27] Kelley, W.P. (1940) Permissible Composition and Concentration of Irrigation Water. Proceedings of the American Society of Civil Engineers, 66, 607-613.

[28] Richards, L.A. (1954) Diagnosis and Improvement of Saline and Alkali Soils, Agricultural Handbook 60. USDA and IBH Publishing Co. Ltd., New Delhi, 98-99.

[29] Wilcox, L.V. (1955) Classification and Use of Irrigation Waters. USDA, Circular 969, Washington DC. 